Kieran T. J. Fitzpatrick MB FFARCSI, Gerard W. Black MD FRCPI FFARCS, Peter M. Crean MB FFARCSI, Rajinder K. Mirakhur MD FFARCS

\title{
Continuous vecuronium infusion for prolonged muscle relaxation in children
}

Facilitation of mechanical ventilation of the hungs using an infusion of vecuronium in 11 infants and children and four neonates in an intensive care unit is described. A loading dose of vecuronium of $0.1 \mathrm{mg} \cdot \mathrm{kg}^{-1}$ was followed by an infusion at an initial rate of $0.1 \mathrm{mg} \cdot \mathrm{kg}^{-1} \cdot \mathrm{hr}^{-1}$. The infusion rate was adjusted to maintain a neuromuscular block of approximately $90 \%$ as assessed by the presence of one response to a train-of-four stimulation. The duration of the infusions varied from 9.510179 $\mathrm{hr}$. The mean dose of vecuronium administered was 0.14 $\mathrm{mg} \cdot \mathrm{kg}^{-1} \cdot \mathrm{hr}^{-1}( \pm 0.05, \mathrm{SD})$ in the children and $0.11 \mathrm{mg}$. $\mathrm{kg}^{-1} \cdot \mathrm{hr}^{-1}( \pm 0.05)$ in the neonates. Mean recovery times from the time of stopping the infusion until absence of apparent fade in response to tetanic stimulation were $51.7( \pm 17.6)$ and 46.8 $( \pm 16.5) \mathrm{min}$ for the children and neonates respectively. No adverse cardiovascular or toxic effects were noted. This technique of vecuronium infusion to facilitate mechanical ventilation of the lungs is feasible and satisfactory in clinical use.

La facilitation de la ventilation mécanique des poumons utilisamt la perfusion de vécuronium chez /I enfants et bébés et quatre nouveau-nés aux soins intensifs est décrite. Une dose de charge de vécuronium de $0.1 \mathrm{mg} \cdot \mathrm{kg}^{-1}$ a été suivie par une perfusion à un taux initial de $0,1 \mathrm{mg} \cdot \mathrm{kg}^{-1} \cdot \mathrm{hre} \mathrm{e}^{-1}$, Le taux de perfusion fut ajusté afin de inaintenir un bloc neuromusculaire d' approximativement $90 \%$ rel qu'évalué par la stimulation de l'ondée-dequatre (TOF). La durée des perfusions a varié de 9,5 à 179

\section{Key words}

ANAESTHESIA: paediatric;

INTENSIVE CARE: ventilation;

NEUROMUSCULAR RELAXANTS: vecuronium.

From the Intensive Care Unit, Royal Belfast Hospital for Sick Children, Belfast BT12 6BE, Northern Ireland

Address correspondence 10 : Dr. R. K. Mirakhur, Department of Anaesthetics, Whitla Medical Building, 97 Lisburn Road, Belfast, Northern Ireland.

This project was supported by financial assistance from the Royal Belfast Hospital for Sick Children and Abbott Laboratories Limited.

Accepted for publication 6ih November, 1990 heures. La dose moyenne de vécuronium administrée élait de $0,14 \mathrm{mg} \cdot \mathrm{kg}^{-1} \cdot \mathrm{hre}^{-1}( \pm 0,05$, SD) chez les enfants et $0,11 \mathrm{mg}$. $\mathrm{kg}^{-1} \cdot \mathrm{hre}^{-1}( \pm 0,05)$ chez les novea-unés. Les temps moyens de récupération à partir du temps de l'arrêt de la perfusion jusqu'à l'absence de l'apparition du fade en réponse à une stimulation tétanique furem $51,7( \pm 17,6)$ el 46,8( $\pm 16,5) \mathrm{min}$. pour les enfants el les nouveau-nés respectivement. Aucun effet cardiovasculaire néfaste ou toxique ne fut noté. Cetté technique de perfusion de vécuronium afin de faciliter la ventilation mécanique est faisable et satisfaisante pour l'utilisation clinique.

Children admitted to an intensive care unit may require mechanical ventilation of the lungs. As in adults the use of muscle relaxants in this context is decreasing. However, it has been shown that the use of pancuronium to facilitate mechanical ventilation speeds the recovery of infants suffering from hyaline membrane disease. ' In addition, neuromuscular blocking agents may be required to facilitate intermittent positive-pressure ventilation when lung compliance is low or when the patient is being stabilised on ventilation.

Traditionally, agents such as pancuronium and dtubocurarine have been used to facilitate mechanical ventilation. However, Fisher et al ${ }^{2}$ have shown that neonates and infants are more sensitive than adults to d-tubocurarine. Similar sensitivity to pancuronium has been shown by Bennett et al. ${ }^{3}$ Furthermore, a greater individual variation in the dose requirements of $d$ tubocurarine in the paediatric age group has been demonstrated by Goudsouzian et al. ${ }^{4}$ Consequently, using a long-acting muscle relaxant to facilitate mechanical ventilation in these circumstances may have unpredictable effects leading to overdosage and delayed recovery in some patients.

Vecuronium is a relatively short-acting neuromuscular blocking agent which is non-cumulative and, in addition, does not have the cardiovascular side-effects of the older muscle relaxants. ${ }^{5}$ It would thus appear to be a suitable agent for use in the intensive care unit. However, because of its short duration of action, administration by an intermittent bolus technique could be impractical. The 
TABLE 1 Patient details (infants and children)

\begin{tabular}{|c|c|c|c|c|c|}
\hline $\begin{array}{l}\text { Pariem } \\
\text { no. }\end{array}$ & $\begin{array}{l}\text { Age } \\
(m+h)\end{array}$ & Sex & $\begin{array}{l}\text { Weight } \\
(k g)\end{array}$ & Diagnosis & Medicarions \\
\hline I & 7 & $\mathbf{M}$ & 8 & Meningitis & $\begin{array}{l}\text { Dopamine } \\
\text { Phenytoin } \\
\text { Chloramphenicol }\end{array}$ \\
\hline 2 & 14 & $M$ & 6 & Pneumonia & $\begin{array}{l}\text { Dopamine } \\
\text { Cefuroxime } \\
\text { Flucloxacillin }\end{array}$ \\
\hline 3 & 2 & $\mathbf{M}$ & 4 & $\begin{array}{l}\text { VSD } \\
\text { Oesophageal atresia }\end{array}$ & $\begin{array}{l}\text { Gentamicin } \\
\text { Ampicillin }\end{array}$ \\
\hline 4 & 59 & $M$ & 16 & Head injury & Ampicillin/Flucloxacillin \\
\hline 5 & 44 & $\mathbf{M}$ & 16 & Pneumonia & $\begin{array}{l}\text { Hydrocortisone } \\
\text { Genlamicin } \\
\text { Benzylpenicillin }\end{array}$ \\
\hline 6 & & & & & \\
\hline 6 & 30) & $\mathbf{M}$ & 15 & $\begin{array}{l}\text { Aspiration pneumonitis } \\
\text { Hypoxia encephalopathy }\end{array}$ & $\begin{array}{l}\text { Phenobarbilone } \\
\text { Metronidazole } \\
\text { Amoxycillin }\end{array}$ \\
\hline 7 & 4 & $\mathbf{M}$ & 4 & $\begin{array}{l}\text { VSD } \\
\text { Pneumonia }\end{array}$ & $\begin{array}{l}\text { Digoxin } \\
\text { Frusemide } \\
\text { Spironalactone } \\
\text { Cefuroxime } \\
\text { Flucloxacillin }\end{array}$ \\
\hline 8 & 12 & M & 12 & $\begin{array}{l}\text { Pneumonia } \\
\text { Septicaemia } \\
\text { Meningitis }\end{array}$ & $\begin{array}{l}\text { Diazepam } \\
\text { Clonazepam } \\
\text { Phenytoin } \\
\text { Dopamine } \\
\text { Ranitidine } \\
\text { Flucloxacillin } \\
\text { Chloramphenicol } \\
\text { Acyclovir }\end{array}$ \\
\hline 9 & 36 & $\mathbf{F}$ & 11 & $\begin{array}{l}\text { Post-thoracolomy } \\
\text { Preumonia }\end{array}$ & $\begin{array}{l}\text { Frusemide } \\
\text { Spironalactone } \\
\text { Amoxycillin } \\
\text { Cefuroxime }\end{array}$ \\
\hline 10 & 42 & $\mathbf{M}$ & 12 & $\begin{array}{l}\text { VSD } \\
\text { Coarctation } \\
\text { Aorta } \\
\text { DORV }\end{array}$ & $\begin{array}{l}\text { Digoxin } \\
\text { Frusemide } \\
\text { Spironalactone } \\
\text { Cimetidine } \\
\text { Dobutamine } \\
\text { Gentamicin } \\
\text { Vancomycin }\end{array}$ \\
\hline II & 137 & M & 36 & Head injury & Ampicillin/Flucloxacillin \\
\hline
\end{tabular}

VSD $=$ Ventricular septal defect.

DORV = Double outlet right ventricle.

drug has been used by continuous infusion in long surgical procedures $^{6}$ and more recently Darrah et al. have reported on its use by infusion for long periods in adults undergoing mechanical ventilation. ${ }^{7}$ it was therefore decided to study the administration of vecuronium by infusion in paediatric patients admitted to a Children's Intensive Care Unit for prolonged mechanical ventilation.

\section{Methods}

The study was reviewed and approved by the Hospital Medical Ethics Committee. A total of 15 patients requir- ing the administration of muscle relaxants to facilitate intermittent positive-pressure ventilation were admitted to the study; 11 infants and children (mean age \pm SD: $35.2 \pm 38.7 \mathrm{mth}$ ), and four neonates (mean age \pm SD: 5.3 $\pm 7.9 \mathrm{~d})$.

Neuromuscular block was established by administering an initial bolus dose of vecuronium of $0.1 \mathrm{mg} \cdot \mathrm{kg}^{-1}$. At the same time an infusion of vecuronium was commenced at a rate of $0.1 \mathrm{mg} \cdot \mathrm{kg}^{-1} \cdot \mathrm{hr}^{-1}$. The vecuronium was delivered from a syringe pump dissolved in $0.18 \%$ saline in $4 \%$ dextrose in a concentration of $0.2 \mathrm{mg} \cdot \mathrm{ml}^{-1}$. In 
TABLE II Vecuronium infusion details (intants and children)

\begin{tabular}{lllllll}
\hline $\begin{array}{l}\text { Patient } \\
\text { no. }\end{array}$ & $\begin{array}{l}\text { Infusion } \\
\text { duration } \\
(\mathrm{hr})\end{array}$ & $\begin{array}{l}\text { Vecuronium } \\
\text { rate } \\
\mathrm{ng} \cdot \mathrm{kg}^{-1} \cdot \mathrm{hr}^{-1}\end{array}$ & $\begin{array}{l}\text { Dose } \\
\text { total } \\
(\mathrm{mg})\end{array}$ & $\begin{array}{l}\text { Rate } \\
\text { Rate } \\
\text { changes }\end{array}$ & $\begin{array}{l}\text { Recovery } \\
\text { ime } \\
(\mathrm{min})\end{array}$ & Oncome \\
\hline 1 & 41.5 & 0.1 & 34 & 19 & 59 & Alive \\
2 & 119.5 & 0.1 & 72.1 & 3 & 73 & Died \\
3 & 21.5 & 0.27 & 21.5 & 13 & 30 & Alive \\
4 & 45.5 & 0.13 & 91.4 & 3 & 51 & Died \\
5 & 34 & 0.17 & 85.3 & 15 & 32 & Alive \\
6 & 13 & 0.14 & 28 & 2 & 45 & Alive \\
7 & 41.5 & 0.11 & 18.5 & 14 & 68 & Alive \\
8 & 179 & 0.12 & 260.4 & 45 & 80 & Alive \\
9 & 15.5 & 0.14 & 23.4 & 15 & 27 & Alive \\
10 & 35.5 & 0.12 & 50.8 & 5 & 49 & Alive \\
11 & 16.5 & 0.12 & 68 & 6 & 55 & Alive \\
Mean & 51.2 & 0.14 & & & 51.7 & 17.6 \\
SD & 51.6 & 0.05 & 68.5 & 12.7 & 12.3 & \\
\hline
\end{tabular}

fluid restricted patients the vecuronium concentration was doubled to $0.4 \mathrm{mg} \cdot \mathrm{ml}^{-1}$.

The degree of neuromuscular blockade was monitored using train-of-four (TOF) nerve stimulation of the ulnar nerve at the wrist or elbow using a Myotest peripheral nerve stimulator (Biometer Ltd). The aim was to maintain a constant block of the adductor pollicis of approximately $90 \%$ (one response to TOF stimulation). A note was made of the number of responses felt in the thumb in response to a TOF stimulation every $30 \mathrm{~min}$. The infusion rate of the vecuronium was maintained constant unless the block remained at $100 \%$ (i.e., no response to TOF stimulation) or the block was less than $80 \%$ (i.e., three or more responses were present) for more than one hour. In these circumstances the infusion was reduced or increased by $10 \%$ of the original rate until one response was present. Recovery times were measured from the time of cessation of the vecuronium infusion to loss of apparent fade in response to a tetanic stimulation. This was done every three to four minutes.

Routine monitoring of the patients was in accordance with the practice of the unit and included ECG, direct arterial pressure and temperature measurement. Arterial blood gas and electrolyte measurements were carried out twice a day or more often if required and adjustments were made to ventilation and acid-base balance as necessary.

Sedation was provided by infusions of morphine (20-40 $\mathrm{\mu g} \cdot \mathrm{kg}^{-1} \cdot \mathrm{hr}^{-1}$ ) except in three neonates who received infusions of fentanyl $\left(10-20 \mu \mathrm{g} \cdot \mathrm{kg}^{-1} \cdot \mathrm{hr}^{-1}\right)$.

Mean values and standard deviations were calculated for the durations of infusion, the dosage required and the time to recovery in the two subgroups of patients. The data were examined for correlation between the duration of infusion and the recovery time.

\section{Results}

Table I lists the details of the 11 inf ants and children in the study. Patient \# 1 was treated with chloramphenicol and all the other children received a penicillin, aminoglycoside or a cephalosporin antibiotic. Except for patients \#9 and \# 10 who required a second bolus, a complete neuromuscular block was achieved following the initial bolus of $0.1 \mathrm{mg} \cdot \mathrm{kg}^{-1}$ vecuronium.

Table II lists the details of the vecuronium infusions in these infants and children. The duration of infusions varied from 13 to $179 \mathrm{hr}$. The dose of vecuronium varied from $0.1 \mathrm{mg} \cdot \mathrm{kg}^{-1} \cdot \mathrm{hr}^{-1}$ to $0.27 \mathrm{mg} \cdot \mathrm{kg}^{-1} \cdot \mathrm{hr}^{-1}$ with a mean of $0.14 \mathrm{mg} \cdot \mathrm{kg}^{-1} \cdot \mathrm{hr}^{-1}( \pm 0.05)$. The total amount of vecuronium administered varied between 18.5 and 260 $\mathrm{mg}$. Also listed is the number of alterations to the infusion rate required to keep the neuromuscular block constant.

The time to recovery varied from 27 to $80 \mathrm{~min}$ with a mean of $51.7 \mathrm{~min}( \pm 17.6)$. There was a positive correlation between the duration of the infusion and the time to recovery from the neuromuscular block in this group ( $\mathrm{r}=0.76 ; P<0.01$ ).

Table I shows that 9 of the $\mathrm{I} I$ inf ants and children were discharged from the intensive care unit. The other two children died from the effects of pneumonia and head injury. All patients maintained a normal blood biochemistry throughout the study.

All four patients in the neonatal group (Table III) achieved complete neuromuscular blockade with the loading dose of $0.1 \mathrm{mg} \cdot \mathrm{kg}^{-1}$ vecuronium. The duration of infusions (Table IV) varied from 9.5 to $64.5 \mathrm{hr}$. The dose of vecuronium varied from $0.07 \mathrm{mg} \cdot \mathrm{kg}^{-1} \cdot \mathrm{hr}^{-1}$ to $0.18 \mathrm{mg} \cdot \mathrm{kg}^{-1} \cdot \mathrm{hr}^{-1}$ with a mean of $0.11 \mathrm{mg} \cdot \mathrm{kg}^{-1} \cdot \mathrm{hr}^{-1}$ $( \pm 0.05)$. The total amount of vecuronium used varied from $1.7 \mathrm{mg}$ to $22.5 \mathrm{mg}$. The time to recovery varied from 
TABLE III Patient delails (neonales)

\begin{tabular}{|c|c|c|c|c|c|}
\hline $\begin{array}{l}\text { Patient } \\
\text { no. }\end{array}$ & $\begin{array}{l}\text { Age } \\
\text { (d) }\end{array}$ & Sex & $\begin{array}{l}\text { Weight } \\
(k g)\end{array}$ & Diagnosis & Medicarions \\
\hline I & I & $\mathbf{M}$ & 3.2 & Diaphragmatic hernia & $\begin{array}{l}\text { Benzylpenicillin } \\
\text { Gentamicin } \\
\text { Cefuroxime } \\
\text { Flucloxacillin }\end{array}$ \\
\hline 2 & $2^{*}$ & $\mathbf{M}$ & 2.6 & RDS & $\begin{array}{l}\text { Benzylpenicillin } \\
\text { Netilmicin }\end{array}$ \\
\hline 3 & 1 & $\mathbf{M}$ & 1.9 & Diaphragmatic hernia & $\begin{array}{l}\text { Benzylpenicillin } \\
\text { Gentanicin } \\
\text { Dopanine }\end{array}$ \\
\hline 4 & 17 & $F$ & 3.8 & $\begin{array}{l}\text { Pneumonia } \\
\text { Situs inversus }\end{array}$ & $\begin{array}{l}\text { Benzylpenicillin } \\
\text { Gentamicin }\end{array}$ \\
\hline
\end{tabular}

Patients 1, 2 and 3 received fentanyl for sedation.

Patient 4 received morphine for sedation.

*Born at 37 wk gestation.

RDS $=$ respiratory distress syndrome

31 to $62 \mathrm{~min}$ with a mean of $47 \mathrm{~min}( \pm 16.5)$. There was no significant correlation between duration of the vecuronium infusion and time to recovery in this sub-group. All four neonates were discharged from the intensive care unit. All patients maintained normal blood biochemistry throughout the study.

No patient exhibited any bradycardia or arrhythmias due to vecuronium administration.

\section{Discussion}

Neuromuscular blocking agents are used less frequently now in the intensive care unit to facilitate intermittent positive-pressure ventilation of patients. Emphasis is placed more upon adequate sedation. However, this does not always provide optimal ventilation and recourse has to be made to administration of a muscle relaxant in conjunction with the sedatives.

The present study demonstrates that it is feasible and satisfactory to administer vecuronium by an infusion technique to children in the intensive care unit. Furthermore, the study has shown that the degree of muscle relaxation can be monitored using a nerve stimulator without need for transducers and recording equipment to ensure adequate neuromuscular blockade. The recovery after stopping the infusions appears to be relatively rapid. Even patient \#8 (Table II), whose infusion lasted $179 \mathrm{hr}$, took only $80 \mathrm{~min}$ to recover adequately from the block. In the infants and children the infusion rate varied from 0.07 $\mathrm{mg} \cdot \mathrm{kg}^{-1} \cdot \mathrm{hr}^{-1}$ to $0.27 \mathrm{mg} \cdot \mathrm{kg}^{-1} \cdot \mathrm{hr}^{-1}$. The latter figure was obtained in a two-month-old, $4 \mathrm{~kg}$, infant with congenital heart disease and oesophageal atresia. The mean infusion rate was $0.14 \mathrm{mg} \cdot \mathrm{kg}^{-1}$. For these children the number of adjustments to the infusion rate varied from 2 to 45 . The adjustments were required throughout the entire infusion period and not only in the early stages. There was a marked inter-patient variability in the number of adjustments required to the infusion. For example, patient \#2 required only three changes to the infusion rate in $119.5 \mathrm{hr}$ while patient \#9 required $15 \mathrm{in} 15.5 \mathrm{hr}$. This confirms the individual variability reported with vecuronium by various workers. ${ }^{8}$

Animal work suggests that a metabolite of metronidazole may inhibit the metabolism of vecuronium. ${ }^{9}$ However, patient \#6 was receiving metronidazole yet the recovery (45 $\mathrm{min}$ ) in this patient did not show any prolongation from the group mean $(51.7 \mathrm{~min})$. This is in agreement with the findings of d'Hollander et al. ${ }^{10}$ Penicillin has been shown to have little effect on neuromuscular function while aminoglycosides prolong the effect of nondepolarizing muscle relaxants. ${ }^{11,12}$ In the present study neither penicillin nor the aminoglycosides appeared to prolong the activity of the vecuronium. Although phenytoin administration has been reported to induce resistance to vecuronium, ${ }^{13}$ this was not observed in the two patients receiving phenytoin in the present study, perhaps because these patients had received phenytoin for only a short time.

An important determinant of the duration of effects of drugs used by continuous infusion in the intensive therapy units is the status of renal function. It has been reported that the effect of vecuronium when used over long periods

TABLE IV Vecuronium infusion details (neonates)

\begin{tabular}{lllllll}
\hline $\begin{array}{l}\text { Patient } \\
\text { no. }\end{array}$ & $\begin{array}{l}\text { Infusion } \\
\text { duration } \\
(\mathrm{hr})\end{array}$ & $\begin{array}{l}\text { Vecuronium } \\
\text { rate } \\
\mathrm{mg} \cdot \mathrm{kg}^{-1} \cdot \mathrm{hr}^{-1}\end{array}$ & $\begin{array}{l}\text { Dose } \\
\text { tolal } \\
(\mathrm{mg})\end{array}$ & $\begin{array}{l}\text { Rate } \\
\text { Rate } \\
\text { changes }\end{array}$ & $\begin{array}{l}\text { Recovery } \\
\text { fime } \\
(\mathrm{min})\end{array}$ & Outcome \\
\hline 1 & 48 & 0.074 & 11.7 & 29 & 60 & Alive \\
2 & 9.5 & 0.07 & 1.74 & 8 & 62 & Alive \\
3 & 64.5 & 0.18 & 22.5 & 5 & 31 & Alive \\
4 & 25 & 0.13 & 12.4 & 1 & 34 & Alive \\
Mean & 36.8 & 0.11 & 12.1 & 10.8 & 46.8 & 16.5 \\
SD & 24.3 & 0.05 & 8.5 & 12.5 & & \\
\hline
\end{tabular}


may be unduly prolonged in the presence of severe renal dysfunction. ${ }^{14,15}$ This is based on the decreased clearance of vecuronium and the cumulation of its active metabolite 3-desacetylvecuronium in patients with renal failure. ${ }^{15,16}$ Delayed recovery was not a problem after the prolonged use of vecuronium in patients with good renal function in adults $^{7}$ and was not observed in the present study where the renal function was good. Nevertheless one must be conscious of this possibility.

In 1955 Stead $^{17}$ showed that the neonate was more sensitive than the adult to the effects of $d$-tubocurarine. More recent work has demonstrated that neonates are also more sensitive to the neuromuscular blocking effects of vecuronium. ${ }^{18}$ Neonates in the present study required a lower infusion rate, an average of $0.11 \mathrm{mg} \cdot \mathrm{kg}^{-1} \cdot \mathrm{hr}^{-1}$ compared with $0.14 \mathrm{mg} \cdot \mathrm{kg}^{-1} \cdot \mathrm{hr}^{-1}$ in the infants and children although this difference was not significant $(P<$ $0.4)$. There was once again a marked variability in the dose requirements (Table IV); however, the results are based on only a very small group of patients. The dosage of vecuronium used in the present study in the neonates was higher than that reported by Meretoja. ${ }^{19}$ However, vecuronium infusions in that study were being used over a relatively short time in ASA I or II patients undergoing elective surgery whereas patients in the present study required pulmunary ventilation for a much longer time due to the presence of infection and high metabolic rates. The lower requirements of vecuronium in children during prolonged infusions reported by Eldadah and Newth were probably because they maintained a more superficial block. ${ }^{20}$

Despite a positive correlation between the duration of the infusion and the recovery time in these infants and children, clinical recovery from the neuromuscular block was not unduly prolonged, the longest time being $80 \mathrm{~min}$ in patient \#8 after an infusion of 179 hr. It does, however, emphasise the importance of monitoring the effects of the vecuronium being infused and tailoring the dose to each patient's requirements.

In conclusion, this study demonstrates the feasibility of administering vecuronium by infusion to children requiring neuromuscular blockade to facilitate intermittent positive pressure ventilation in the intensive care unit. Control of the infusion to maintain constant neuromuscular blockade was readily achieved using a peripheral nerve stimulator.

\section{Acknowledgements}

We would like to thank the nursing staff of the Intensive Care Unit of the Royal Belfast Hospital for Sick Children for their cooperation in this study.

\section{References}

1 Pollizer M, Reynolds EDR, Shaw DR, Thomas RM. Pancuronium during mechanical ventilation speeds recovery of lungs of infants with hyaline membranc disease. Lancet 1981; 1: 364-3.

2 Fisher DM, O'Keefe C, Stonskj DR, Crommelly $R$, Miller $R D$, Gregory $G A$. Pharmacokinetics and pharmacodynamics of d-tubocurarine in infunts, children and adults. Anesthesiology 1982; 57: 203-8.

3 Bennett EJ, Ramamurthy S. Dalal FY, Salem MR. Pancuronium and the neonate. Br J Anaesth 1975; 47: 75-8.

4 Goudsouzian NG, Donlan JV, Savarese JJ, Ryan JF. Reevaluation of dosage and duration of action of $d$ tubocurarine in the paediatric age group. Anesthesiology 1975; 43: 416-25.

5 Miller RD. Vecuronium. Seminars in Anesthesia 1984; 3: 312-8.

6 Mirakhur RK, Ferres CJ. Muscle relaxation with an infusion of vecuronium. Eur J Anaesthesiol 1984; 1: 353-9.

7 Darrah WC, Johnston JR, Mirakhur RK. Vecuronium infusions for prolonged muscle relaxation in the intensive care unit. Crit Care Med 1989; 17: 1297-300.

8 Fisher DM, Canfell C, Miller RD. Pharnacokinetics and pharmacodynamics of vecuronium in anesthetised infants and children. Clin Pharmacol Ther 1985; 37: 402-6.

9 McIndewar IC, Marshall RJ. Interactions between the neuromuscular blocking drug Org NC45 and some anaesthetic, analgesic and antimicrobial agents. $\mathrm{Br} J$ Anaesth 1981; 53: 785-92.

10 D'Hollander A, Agosion S, Capouet V. Failure of metronidazole to alter a vecuronium neuromuscular blockade in humans. Anesthesiology 1985; 63: 99-102.

11 Sokoll MD, Gergis SD. Antibiotics and neuromuscular function. Anesthesiology 1981; 55: 148-59.

12 Dupuis $J Y$, Martin R, Tetrault JP. Atracurium and vecuronium interaction with gentamicin and tobramycin. Can J Anaesth 1989; 36: 407-11.

13 Ornstein E, Matteo RS, Schwartz AE, Silverberg $P A$ Young WL, Diaz J. The effect of phenytoin on the magnitude and duration of neuromuscular block following atracurium or vecuronium. Anesthesiology 1987; 67: $191-6$.

14 Smith $C L$, Hunter JM, Jones RS. Vecuronium infusions in patients with renal failure in an ITU. Anaesthesia 1987; 42: 387-93.

15 Segredo V, Matthay MA, Sharma ML, Grufnke LD, Caldwell $J E$, Miller RD. Prolonged neuromuscular blockade after long term administration of vecuronium in two critically ill patients. Anesthesiology 1990; 72: 566-70. 
16 Lynam DP, Cronnelly $R$, Castagnoli BS et al. The pharmacodynamics and pharmacokinetics of vecuronium in patients anesthetised with isoflurane with normal renal function or with renal failure. Anesthesiology 1988; 69: 227-31.

17 Stead $A L$. The response of the newborn infant to muscle relaxants. Br J Anaesth 1955; 27: 124-30.

18 Meretoja $O A$. Is vecuronium a long-acting neuromuscular blocking agent in neonates and infants? Br J Anaesth 1989; 62: 184-7.

19 Mereroja $O A$. Vecuronium infusion requirements in pediatric patients during fentanyl- $\mathrm{N}_{2} \mathrm{O}-\mathrm{O}_{2}$ anesthesia. Anesth Analg 1989; 68: 20-4

20 Eldaddah $M K$, Newth $C J L$. Vecuronium by continuous infusion for neuromuscular blockade in infants and children. Crit Care Med 1989; 17: 989-92. 